\title{
A mesoporous Fe/N/C ORR catalyst for polymer electrolyte membrane fuel cells
}

\author{
Wei Shi a, Yu-Cheng Wang a, Chi Chen a,b, Xiao-Dong Yang a,\#, Zhi-You Zhou a,*, Shi-Gang Sun ${ }^{\text {a }}$ \\ a State Key Laboratory of Physical Chemistry of Solid Surfaces, Collaborative Innovation Center of Chemistry for Energy Materials, College of Chemistry \\ and Chemical Engineering, Xiamen University, Xiamen 361005, Fujian, China \\ b State Key Laboratory of Chemical Engineering, College of Chemical Engineering, East China University of Science and Technology, Shanghai 200237, \\ China
}

\section{A R T I C L E I N F O}

\section{Article history:}

Received 17 April 2016

Accepted 11 May 2016

Published 5 July 2016

Keywords:

$\mathrm{Fe} / \mathrm{N} / \mathrm{C}$ catalyst

Non-platinum catalyst

Oxygen reduction reaction

Mesopore

Hollow-shell structure

\begin{abstract}
A B S T R A C T
$\mathrm{Fe} / \mathrm{N} / \mathrm{C}$ is a promising non-platinum catalyst for the oxygen reduction reaction (ORR). Even so, mass transfer remains a challenge in the application of $\mathrm{Fe} / \mathrm{N} / \mathrm{C}$ to proton exchange membrane fuel cells, due to the high catalyst loadings required. In the present work, mesoporous Fe/N/C was synthesized through heat treatment of KJ600 carbon black coated with poly-2-aminobenzimidazole and $\mathrm{FeCl}_{3}$. The as-prepared $\mathrm{Fe} / \mathrm{N} / \mathrm{C}$ possesses a unique hollow-shell structure that contains a buffer zone allowing both water formation and vaporization, and also facilitates the mass transfer of gaseous oxygen. This catalyst generated an oxygen reduction reaction activity of $9.21 \mathrm{~A} / \mathrm{g}$ in conjunction with a peak power density of $0.71 \mathrm{~W} / \mathrm{cm}^{2}$.
\end{abstract}

(C) 2016, Dalian Institute of Chemical Physics, Chinese Academy of Sciences. Published by Elsevier B.V. All rights reserved.

\section{Introduction}

Proton exchange membrane fuel cells (PEMFCs) are promising clean energy generation devices. One of the major impediments to their commercialization is the sluggish kinetics of the oxygen reduction reaction (ORR). To date, the ternary $\mathrm{Fe} / \mathrm{N} / \mathrm{C}$ system has been extensively developed as the most promising ORR catalyst among the non-platinum candidates. Initially, $\mathrm{Fe} / \mathrm{N} / \mathrm{C}$ was obtained by pyrolyzing $\mathrm{Fe}-\mathrm{N}_{4}$ or $\mathrm{Co}-\mathrm{N}_{4}$ macrocycles adsorbed on a carbon support in an inert atmosphere [1]. More recently, several methods have been developed to improve the catalyst's ORR activity and stability, as well as to lower the cost. As an example, ball milling of precursors and two-step pyrolysis in $\mathrm{Ar}$ and $\mathrm{NH}_{3}$ atmospheres have been found to greatly boost the ORR activity of the $\mathrm{Fe} / \mathrm{N} / \mathrm{C}$ catalyst, providing a high ORR activity of $4.30 \mathrm{~A} / \mathrm{g}$ at $0.9 \mathrm{~V}$ during rotating disk electrode (RDE) trials [2,3]. Fe/N/C has also been obtained by coating a heteroatom polymer on various precursors through pyrolysis-acid leaching-pyrolysis. The obtained Fe/N/C exhibited a high ORR activity of approximately $6.7 \mathrm{~A} / \mathrm{g}$ at $0.80 \mathrm{~V}$ [4]. Further improvements have been made by adding various procedures to the pyrolysis-acid leaching process, resulting in an ORR activity of $21.0 \mathrm{~A} / \mathrm{g}$ at $0.8 \mathrm{~V}$ [5]. Alternatively, $\mathrm{S}$-doped $\mathrm{Fe} / \mathrm{N} / \mathrm{C}$ synthesized using a $\mathrm{Fe}(\mathrm{SCN})_{3}$ precursor has been shown to increase the ORR activity to $23.0 \mathrm{~A} / \mathrm{g}$ at $0.8 \mathrm{~V}$ [6].

\footnotetext{
* Corresponding author. Tel: +86-592-2180181; E-mail: zhouzy@xmu.edu.cn

\# Corresponding author. Tel: +86-592-2180181; E-mail: xiaodong_yang@xmu.edu.cn

This work was supported by the National Basic Research Program of Chain (973 Program, 2015CB932300), the National Natural Science Foundation of China (21373175, 21321062, 21361140374), and Fundamental Research Funds for the Central Universities (20720150109). DOI: 10.1016/S1872-2067(16)62471-3 | http://www.sciencedirect.com/science/journal/18722067 | Chin. J. Catal., Vol. 37, No. 7, July 2016
} 
Along with this significant progress in the preparation of $\mathrm{Fe} / \mathrm{N} / \mathrm{C}$ catalysts with high ORR activity, explorations of their applications in PEMFCs have been attempted by several groups $[2,4,6] . \mathrm{Fe} / \mathrm{N} / \mathrm{C}$ catalysts are low cost, but appropriate levels of fuel cell performance require extremely high $\mathrm{Fe} / \mathrm{N} / \mathrm{C}$ loadings in the PEMFC (approximately $4 \mathrm{mg} / \mathrm{cm}^{2}$ ), which results in poor mass transfer. Typically, the thickness of the Fe/N/C cathode is on the order of $100 \mu \mathrm{m}$, a value that is about 10 times that of a $\mathrm{Pt} / \mathrm{C}$-based catalyst layer. A design incorporating array channels/pores on the meso- or macro-scale has been reported to facilitate mass transfer. As well, the synthesis of metal/N/C catalysts using a foaming agent $[7,8]$ or mesoporous silica templates $[9,10]$ to control the pore structure has been described, and these approaches have led to some improvements in mass transfer.

Herein, we report a non-template method for the preparation of a mesoporous $\mathrm{Fe} / \mathrm{N} / \mathrm{C}$ catalyst, using 2-aminobenzimidazole (2-ABI) as the nitrogen source. In this method, the catalyst (denoted as $\mathrm{Fe} / \mathrm{N} / \mathrm{C}-\mathrm{ABI}$ ) is synthesized through polymerizing 2-ABI on $\mathrm{KJ} 600$ carbon black and $\mathrm{FeCl}_{3}$, followed by pyrolysis. This technique was found to generate abundant mesopores that facilitate mass transfer and improve the PEMFC performance.

\section{Experimental}

\subsection{Synthesis of the $\mathrm{Fe} / \mathrm{N} / \mathrm{C}$-ABI catalyst}

A schematic showing the synthesis of $\mathrm{Fe} / \mathrm{N} / \mathrm{C}-\mathrm{ABI}$ is provided in Fig. 1. As a first step, KJ600 carbon black was pretreated in concentrated nitric acid for $5 \mathrm{~h}$ at $80{ }^{\circ} \mathrm{C}$ to remove any residual metals. The acid-pretreated KJ600 carbon black $(0.25 \mathrm{~g})$ and 2-ABI (1.33 g) were subsequently dispersed in 50 $\mathrm{mL}$ water by sonication and magnetic stirring. Following this, $10 \mathrm{~mL}$ of a $\mathrm{NaClO}$ solution (8\%) was added dropwise with

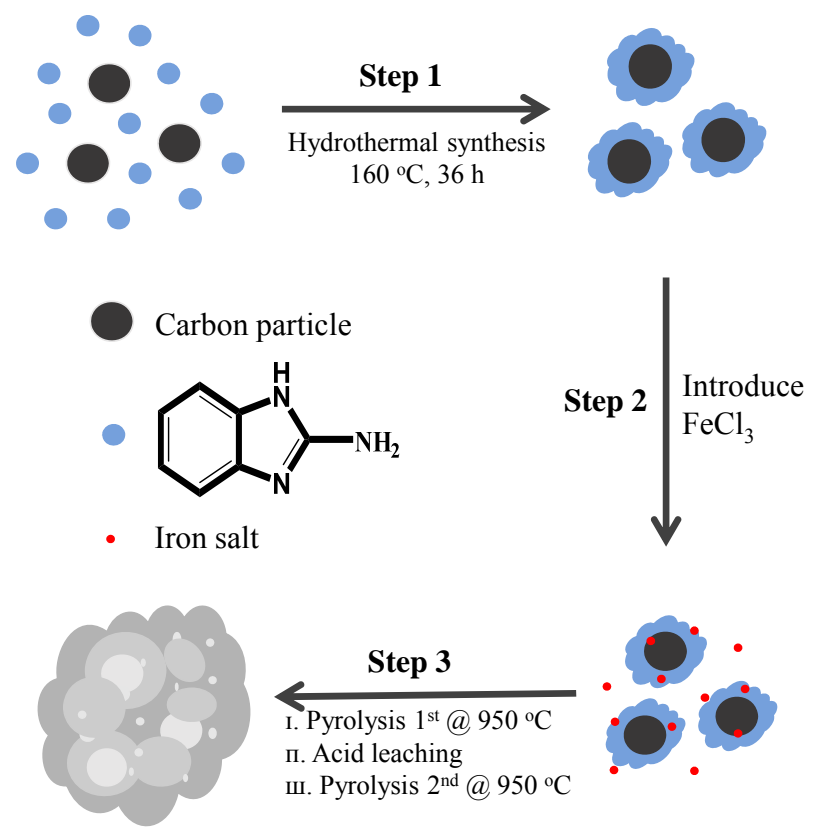

Fig. 1. Procedure for the synthesis of Fe/N/C-ABI. magnetic stirring. The homogeneously dispersed suspension was transferred into a $100 \mathrm{~mL}$ autoclave and the 2-ABI was hydrothermally polymerized at $160{ }^{\circ} \mathrm{C}$ for $36 \mathrm{~h}$, such that poly-2-ABI was coating onto the carbon nanoparticles. Following this, the $\mathrm{ABI} / \mathrm{KJ} 600$ precipitate was filtered, washed with deionized water, and dried overnight at $80^{\circ} \mathrm{C}$. Iron was added by ultrasonic dispersion of a $\mathrm{FeCl}_{3}$ solution ( $1 \mathrm{~mol} / \mathrm{L}, 1 \mathrm{~mL}$ ) with the as-prepared $\mathrm{ABI} / \mathrm{KJ} 600$ powder $(0.3 \mathrm{~g})$ in $100 \mathrm{~mL}$ water, followed by removal of the solvent and drying at $80{ }^{\circ} \mathrm{C}$ for $12 \mathrm{~h}$. The first heat treatment was applied at $950^{\circ} \mathrm{C}$ in an $\mathrm{Ar}$ atmosphere for $1 \mathrm{~h}$. The pyrolyzed powder was then acid leached in $1 \mathrm{~mol} / \mathrm{L} \mathrm{HCl}$ at $80^{\circ} \mathrm{C}$ for $8 \mathrm{~h}$. The sample was subjected to a second heat treatment at $950^{\circ} \mathrm{C}$ in Ar for $3 \mathrm{~h}$. This synthesis was similar to our previous method, in which poly-m-phenylenediamine (PmPDA) was used as the nitrogen precursor [11]. The Fe/N/C-PmPDA catalyst has few mesopores, so it was used as a control material in this study.

\subsection{Rotating ring-disk electrode measurements}

Rotating ring-disk electrode (RRDE, Pine Inc.) tests were performed in a three-electrode electrochemical cell within a 30 ${ }^{\circ} \mathrm{C}$ water bath using a CHI bi-potentiostat (CHI-760E). A RRDE with a Pt ring and a glassy carbon disk (GC, $\phi=5.61 \mathrm{~mm}$, geometric area $=0.2475 \mathrm{~cm}^{2}$ ) was employed as the working electrode, while a graphite plate and a reversible hydrogen electrode (RHE) were used as the counter electrode and reference electrode, respectively. To deposit the catalyst onto the GC disk electrode, a $6.0 \mathrm{mg}$ catalyst sample was ultrasonically dispersed in a combination of $0.5 \mathrm{~mL}$ water, $0.5 \mathrm{~mL}$ ethanol and 50 $\mu \mathrm{L}$ of a Nafion solution ( $5 \mathrm{wt} \%$ ) over $1 \mathrm{~h}$ to form a homogeneous catalyst ink. Subsequently, $25 \mu \mathrm{L}$ of the ink was dropped onto the GC disk of the RRDE, resulting in a catalyst loading of $0.6 \mathrm{mg} / \mathrm{cm}^{2}$. The ORR performance tests were conducted in an $\mathrm{O}_{2}$-saturated $0.1 \mathrm{~mol} / \mathrm{L} \mathrm{H}_{2} \mathrm{SO}_{4}$ electrolyte. The working electrode was subjected to potential cycling between 1.0 and $0.2 \mathrm{~V}$ (RHE) at a scan rate of $10 \mathrm{mV} / \mathrm{s}$ with a rotation rate of 900 $\mathrm{r} / \mathrm{min}$. The background capacitive current was recorded in $\mathrm{N}_{2}$-saturated electrolyte under the same test conditions. This background current was subtracted from the current recorded in the $\mathrm{O}_{2}$-saturated solution to determine the net ORR current. To correct for the effects of mass transfer, the kinetic current $\left(i_{\mathrm{k}}\right)$ was calculated using the Koutecky-Levich equation:

$$
1 / i=1 / i_{\mathrm{L}}+1 / i_{\mathrm{k}}
$$

where $i$ is the current obtained from polarization curves, $i_{\mathrm{L}}$ is the limited diffusion current, and $i_{\mathrm{k}}$ is the kinetic current. The $i_{\mathrm{k}}$ term was normalized by the catalyst loading on the electrode surface to obtain the mass activity.

\subsection{Membrane-electrode assembly performance tests}

Membrane electrode assemblies (MEAs) were prepared using the hot-pressing method. The cathode ink was prepared by ultrasonic mixing of the desired amounts of Fe/N/C-ABI catalyst powder, deionized water, and a Nafion solution (5 wt\%) in an ice bath over $1 \mathrm{~h}$. The ink was directly deposited onto a gas diffusion layer (GDL, PTFE-pretreated Toray 060 carbon paper) 
at a $\mathrm{Fe} / \mathrm{N} / \mathrm{C}-\mathrm{ABI}$ catalyst loading of $4.0 \mathrm{mg} / \mathrm{cm}^{2}$. Commercial $\mathrm{Pt} / \mathrm{C}(40 \%)$ was used as the anode catalyst at a loading of 0.4 $\mathrm{mgPt} / \mathrm{cm}^{2}$. The MEA was fabricated by hot-pressing the as-prepared cathode together with an anode, a Nafion membrane (NRE 211), and a gasket at $135^{\circ} \mathrm{C}$ and $3 \mathrm{MPa}$ for $2 \mathrm{~min}$. The active area of the MEA was $1.0 \mathrm{~cm} \times 1.0 \mathrm{~cm}$. Polarization curves were obtained at $80{ }^{\circ} \mathrm{C}$ using a Model 850 e fuel cell test system (Scribner Associates, Inc.) in conjunction with a back pressure of 1 bar. The $\mathrm{H}_{2}$ and $\mathrm{O}_{2}$ flow rates were $0.3 \mathrm{~L} / \mathrm{min}$ at $100 \% \mathrm{RH}$ during the polarization curve measurements.

\section{Results and discussion}

Fig. 2(a) presents the data obtained from X-ray photoelectron spectroscopy (XPS) of Fe/N/C-ABI. The catalyst evidently contained $\mathrm{C}, \mathrm{N}, \mathrm{O}$, and $\mathrm{Fe}$, at mass proportions of $93.5 \%, 1.79 \%$, $4.32 \%$, and $0.39 \%$, respectively. The ratio between $\mathrm{C}$ and $\mathrm{N}$ was confirmed by CHNS elemental analysis, with a value of 49.6 from the elemental analysis compared to 52.2 from XPS. The much lower $\mathrm{N}$ and Fe contents in the catalyst compared to the precursor can be attributed to losses during the synthetic procedure. The high resolution $\mathrm{N} 1 s$ spectrum in Fig. 2(b) can be resolved into five peaks, assigned to cyano-N, pyridic- $\mathrm{N}, \mathrm{Fe}-\mathrm{N}$, pyrrolic-N, and graphitic N-0, at 398.1, 398.8, 399.8, 400.7, and $402.3 \mathrm{eV}$, respectively, with relative proportions of $4.6 \%, 7.0 \%$, $6.1 \%, 25.0 \%$, and $57.2 \%$.

Fig. 2(c) presents a transmission electron microscopy (TEM) image of the Fe/N/C-ABI. It shows a carbon nanoparticle less than $100 \mathrm{~nm}$ in diameter with a hollow-shell structure. The thickness of the graphite shell is approximately $10 \mathrm{~nm}$ while the hollow region is 10 to $25 \mathrm{~nm}$. In addition, no crystalline metal or metal carbide phases, which would show up as regions of high contrast in the TEM image, are observed.

Fig. 2(d) presents the Ar adsorption-desorption isotherms obtained from the $\mathrm{Fe} / \mathrm{N} / \mathrm{C}-\mathrm{ABI}$, which evidently conform to a type IV isotherm. The hysteresis in the adsorption and desorption isotherms indicates the presence of mesopores, and this is confirmed by the mesopore distribution (obtained via the Barret-Joyner-Halenda (BJH) method) shown in Fig. 2(e). The most common mesopore size is about $20 \mathrm{~nm}$, which is consistent with the TEM observation (Fig. 2(c)). In this work, Fe/N/C-PmPDA previously synthesized by our group [11] was used as a comparison. The Fe/N/C-PmPDA produced isotherms quite different from those of the $\mathrm{Fe} / \mathrm{N} / \mathrm{C}-\mathrm{ABI}$, and few mesopores were observed in this material. Nevertheless, the two catalysts had similar Brunauer-Emmett-Teller (BET) surface areas: 662 vs. $656 \mathrm{~m}^{2} / \mathrm{g}$ for Fe/N/C-ABI and Fe/N/C-PmPDA, respectively.

Fig. 3(a) compares the ORR polarization curves obtained from the $\mathrm{Fe} / \mathrm{N} / \mathrm{C}-\mathrm{ABI}$ and $\mathrm{Fe} / \mathrm{N} / \mathrm{C}-\mathrm{PmPDA}$ catalysts in an $\mathrm{O}_{2}$-saturated $0.1 \mathrm{~mol} / \mathrm{L} \mathrm{H}_{2} \mathrm{SO}_{4}$ solution. The catalytic activity of the $\mathrm{Fe} / \mathrm{N} / \mathrm{C}$-PmPDA was slightly higher than that of the $\mathrm{Fe} / \mathrm{N} / \mathrm{C}-\mathrm{ABI}$, with similar half-wave potentials $(0.807$ vs. 0.820 V). Mass activity was used to quantitatively compare the intrinsic activities of these materials. The currents of the Fe/N/C-ABI and $\mathrm{Fe} / \mathrm{N} / \mathrm{C}-\mathrm{PmPDA}$ at $0.80 \mathrm{~V}$ were 2.55 and $2.64 \mathrm{~mA} / \mathrm{cm}^{2}$, and (a)
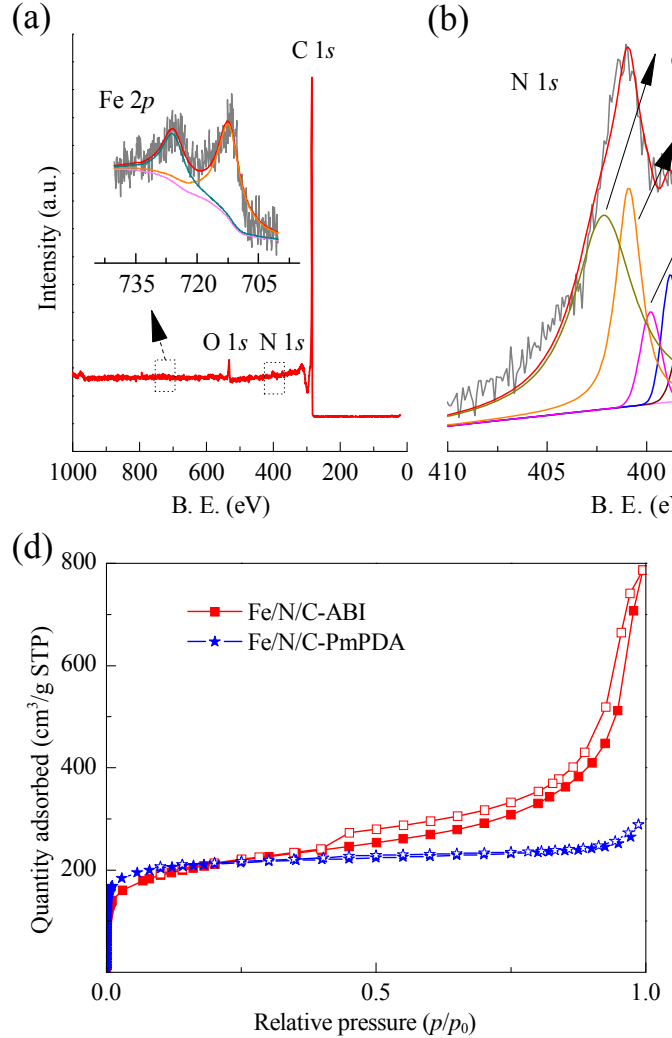

(b)

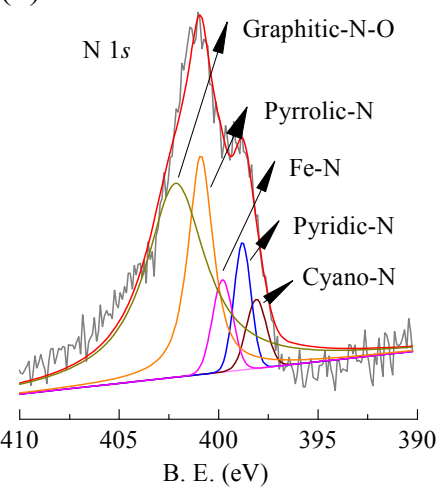

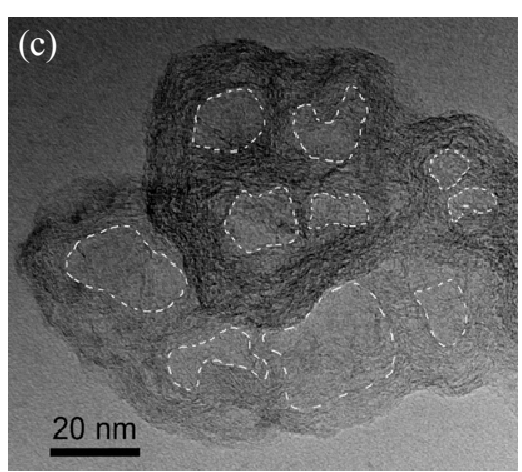

(e)

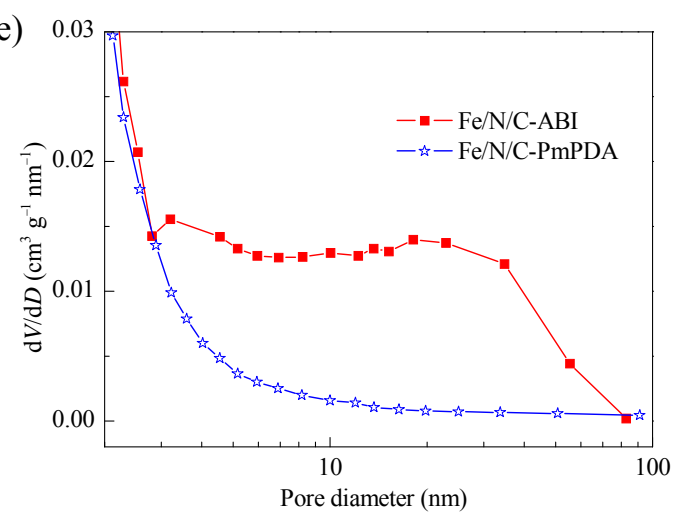

Fig. 2. XPS spectra (a,b) and TEM image (c) of the Fe/N/C-ABI catalyst. (d) Ar adsorption-desorption isotherms obtained from Fe/N/C-ABI and Fe/N/C-PmPDA. Filled symbols: adsorption; hollow symbols: desorption. (e) Mesopore size distributions of Fe/N/C-ABI and Fe/N/C-PmPDA. 

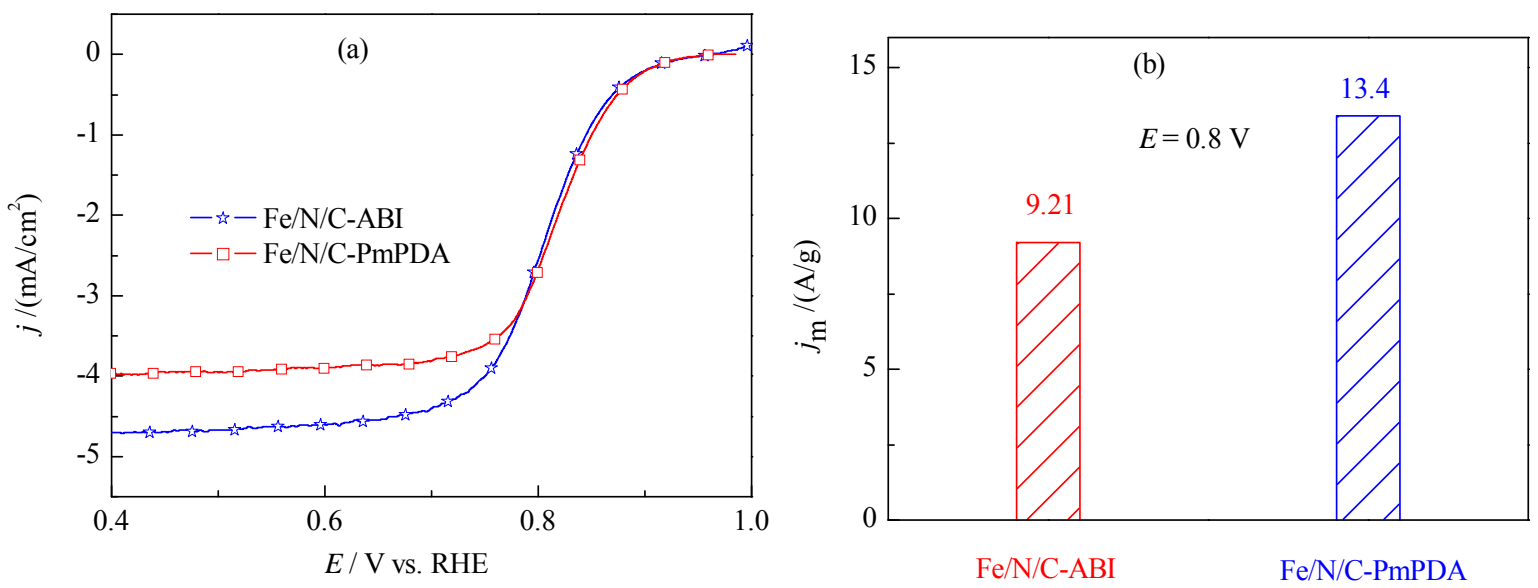

Fig. 3. (a) ORR polarization curves of $\mathrm{Fe} / \mathrm{N} / \mathrm{C}-\mathrm{ABI}$ and $\mathrm{Fe} / \mathrm{N} / \mathrm{C}-\mathrm{PmPDA}$ in an $\mathrm{O}_{2}$-saturated $0.1 \mathrm{~mol} / \mathrm{L} \mathrm{H}_{2} \mathrm{SO}_{4}$ solution. Rotating speed: $900 \mathrm{r} / \mathrm{min}$; scan rate: $10 \mathrm{mV} / \mathrm{s} ; \mathrm{Fe} / \mathrm{N} / \mathrm{C}$ catalyst loading: $0.6 \mathrm{mg} / \mathrm{cm}^{2} ; 30{ }^{\circ} \mathrm{C}$ water bath. (b) A comparison of the kinetic currents at $0.80 \mathrm{~V}$ of the $\mathrm{Fe} / \mathrm{N} / \mathrm{C}-\mathrm{ABI}$ and $\mathrm{Fe} / \mathrm{N} / \mathrm{C}-\mathrm{PmPDA}$.

the limited diffusion currents were 4.71 and $3.97 \mathrm{~mA} / \mathrm{cm}^{2}$, respectively. The catalyst loading on the RDE was $0.6 \mathrm{mg} / \mathrm{cm}^{2}$ and, according to Eq. (1), the mass activity values of the $\mathrm{Fe} / \mathrm{N} / \mathrm{C}-\mathrm{ABI}$ and Fe/N/C-PmPDA were 9.21 and $13.4 \mathrm{~A} / \mathrm{g}$ at 0.8 $\mathrm{V}$, respectively (Fig. 3(b)). Note that the porous distribution did not influence the kinetic mass activity in the RDE tests because this activity is controlled by electrochemical kinetics and not by mass transfer.

We also fabricated MEAs with $\mathrm{Fe} / \mathrm{N} / \mathrm{C}-\mathrm{ABI}$ and $\mathrm{Fe} / \mathrm{N} / \mathrm{C}$-PmPDA as the cathode catalysts. Fig. 4 presents the polarization curves and power densities of the PEMFCs. Consistent with the RDE data, similar catalytic activities were observed at low current density $\left(<0.2 \mathrm{~A} / \mathrm{cm}^{2}\right)$, with slight higher activity exhibited by the Fe/N/C-PmPDA. In this region, the fuel cell performance is controlled by electrochemical kinetics. In contrast, at higher current density values $\left(>0.2 \mathrm{~A} / \mathrm{cm}^{2}\right)$, the PEMFC with $\mathrm{Fe} / \mathrm{N} / \mathrm{C}-\mathrm{ABI}$ showed much better performance. The peak power densities were 0.710 and $0.616 \mathrm{~W} / \mathrm{cm}^{2}$ for the

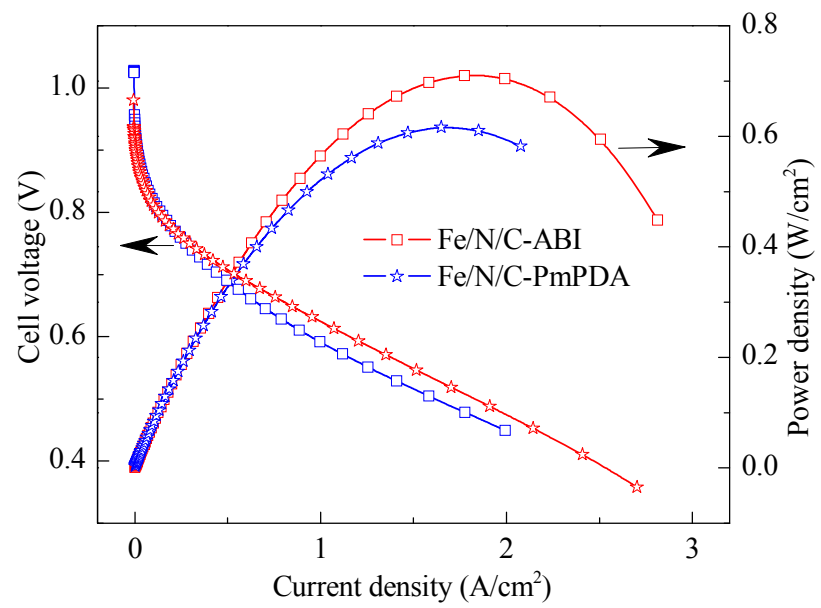

Fig. 4. Polarization and power density plots for $\mathrm{H}_{2}-\mathrm{O}_{2}$ PEMFCs with $\mathrm{Fe} / \mathrm{N} / \mathrm{C}-\mathrm{ABI}$ and $\mathrm{Fe} / \mathrm{N} / \mathrm{C}-\mathrm{PmPDA}$ as cathode catalysts. Temperature: 80 ${ }^{\circ} \mathrm{C}$; back pressure: 1 bar; flow rate: $0.3 \mathrm{~L} / \mathrm{min}$; MEA active area: $1.0 \mathrm{~cm}^{2}$; NRE 211 membrane; cathode catalyst loading: $4.0 \mathrm{mg} / \mathrm{cm}^{2}$; anode catalyst: Pt/C (40 wt\%, JM) with $0.4 \mathrm{mg}_{\mathrm{Pt}} / \mathrm{cm}^{2}$.
$\mathrm{Fe} / \mathrm{N} / \mathrm{C}-\mathrm{ABI}$ and $\mathrm{Fe} / \mathrm{N} / \mathrm{C}-\mathrm{PmPDA}$ devices, respectively.

The voltage can be seen to have varied with current density in an almost linear manner at high current densities. In this region, the mass transfer is more important than the electrochemical kinetics, and thus dominates the cell performance. Therefore, the better performance of the PEMFC with $\mathrm{Fe} / \mathrm{N} / \mathrm{C}-\mathrm{ABI}$ at high current density values indicates better mass transfer than the Fe/N/C-PmPDA device. This can be explained by the unique hollow-shell structure of the Fe/N/C-ABI. Generally, much of the water produced by the ORR is in the liquid state, and this liquid water will flood parts of the cathode, dramatically decreasing $\mathrm{O}_{2}$ transfer. The hollow shells of the $\mathrm{Fe} / \mathrm{N} / \mathrm{C}-\mathrm{ABI}$ nanoparticulates likely act as buffer zones for water formation and vaporization, and so facilitate the mass transfer of oxygen gas. The loading of the $\mathrm{Fe} / \mathrm{N} / \mathrm{C}$ required to maximize PEMFC performance is much higher than that required when using state-of-the-art $\mathrm{Pt} / \mathrm{C}$, and so mass transfer normally becomes a bottleneck. In this work, however, the unique mesoporous structure of the catalyst was found to facilitate mass transfer, providing an ideal solution to the mass transfer issue associated with $\mathrm{Fe} / \mathrm{N} / \mathrm{C}$ applications in PEMFCs.

\section{Conclusions}

A Fe/N/C catalyst having a unique hollow-shell structure with abundant mesopores was synthesized without using a template. The hollow shell structure facilitated mass transfer when this material was employed in a PEMFC, and resulted in a high power density output of $0.71 \mathrm{~W} / \mathrm{cm}^{2}$. This study demonstrates a new strategy for the preparation of $\mathrm{Fe} / \mathrm{N} / \mathrm{C}$ catalysts with improved mass transfer in PEMFCs.

\section{References}

[1] J. H. Zagal, F. Bedioui, J. P. Dodelet, N4-Macrocyclic Metal Complexes, Springer, 2006, 83-147.

[2] M. Lefèvre, E. Proietti, F. Jaouen, J. P. Dodele, Science, 2009, 324, 71-74.

[3] A. Zitolo, V. Goellner, V. Armel, M. T. Sougrati, T. Mineva, L. 


\title{
Graphical Abstract
}

Chin. J. Catal., 2016, 37: 1103-1108 doi: 10.1016/S1872-2067(16)62471-3

\section{A mesoporous $\mathrm{Fe} / \mathrm{N} / \mathrm{C}$ ORR catalyst for polymer electrolyte membrane fuel cells}

Wei Shi, Yu-Cheng Wang, Chi Chen, Xiao-Dong Yang*, Zhi-You Zhou*, Shi-Gang Sun Xiamen University; East China University of Science and Technology
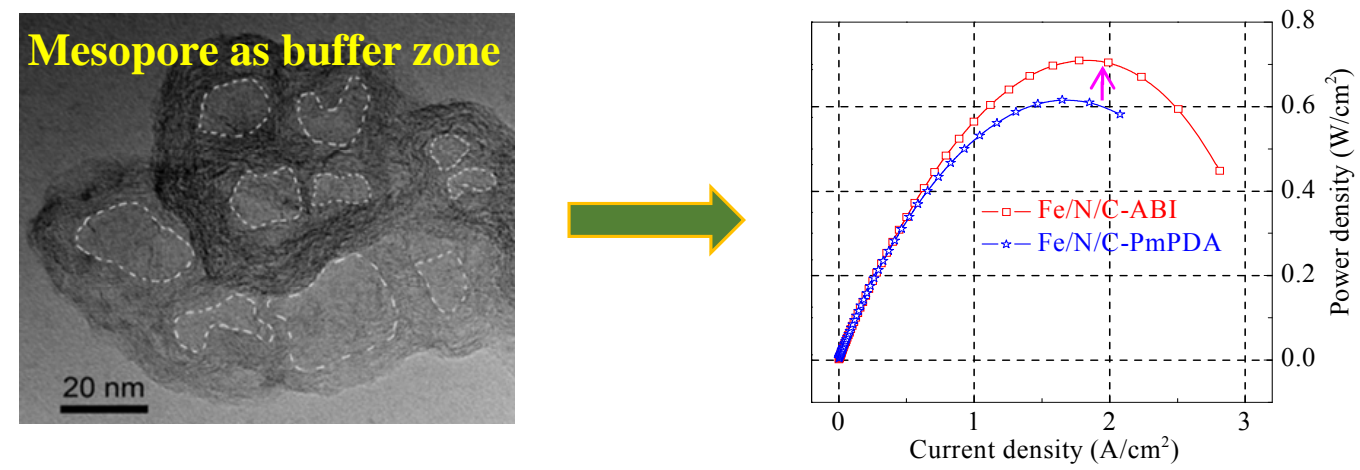

Mesoporous $\mathrm{Fe} / \mathrm{N} / \mathrm{C}$ was prepared without using a template, and this technique was found to facilitate mass transfer and improve the performance of the catalyst in polymer electrolyte membrane fuel cells.

Stievano, E. Fonda, F. Jaouen, Nat. Mater., 2015, 14, 937-942.

[4] G. Wu, K. L. More, C. M. Johnston, P. Zelenay, Science, 2011, 332, 443-447.

[5] N. R. Sahraie, U. I. Kramm, J. Steinberg, Y. J. Zhang, A. Thomas, T. Reier, J. P. Paraknowitsch, P. Strasser, Nat. Commun., 2015, 6, 8618.

[6] Y. C. Wang, Y. J. Lai, L. Song, Z. Y. Zhou, J. G. Liu, Q. Wang, X. D. Yang, C. Chen, W. Shi, Y. P. Zheng, M. Rauf, S. G. Sun, Angew. Chem. Int. Ed., 2015, 54, 9907-9910.

[7] U. I. Koslowski, I. Abs-Wurmbach, S. Fiechter, P. Bogdanoff, J. Phys.
Chem. C, 2008, 112, 15356-15366.

[8] J. M. Ziegelbauer, T. S. Olson, S. Pylypenko, F. Alamgir, C. Jaye, P. Atanassov, S. Mukerjee, J. Phys. Chem. C, 2008, 112, 8839-8849.

[9] A. Garsuch, R. d'Eon, T. Dahn, O. Klepel, R. R. Garsuch, J. R. Dahn, J. Electrochem. Soc., 2008, 155, B236-B243.

[10] A. Garsuch, K. MacIntyre, X. Michaud, D. A. Stevens, J. R. Dahn, J. Electrochem. Soc., 2008, 155, B953-B957.

[11] Q. Wang, Z. Y. Zhou, Y. J. Lai, Y. You, J. G. Liu, X. L. Wu, E. Terefe, C. Chen, L. Song, M. Rauf, N. Tian, S. G. Sun, J. Am. Chem. Soc., 2014, 136, 10882-10885.

\section{介孔结构 $\mathrm{Fe} / \mathrm{N} / \mathrm{C}$ 作为质子交换膜燃料电池氧还原催化剂}

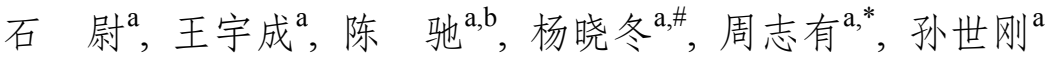 \\ a厦门大学化学化工学院, 能源材料化学创新中心, 固体表面物理化学国家重点实验室, 福建厦门361005 \\ b华东理工大学化学工程国家重点实验室, 上海200237
}

摘要: 燃料电池具有高效、低排放等优势, 非常有希望作为未来电动汽车的能源转化装置. 目前, 燃料电池的商业化受制于 昂贵的铂基催化剂, 特别是动力学迟缓的阴极氧还原反应(ORR)铂催化剂. $\mathrm{Fe} / \mathrm{N} / \mathrm{C}$ 被认为是最有潜力的 $\mathrm{ORR}$ 非贵金属催化 剂, 但其活性仍远低于Pt催化剂, 必须依靠增加载量来弥补其与Pt催化剂的活性差距. 然而, 较厚的催化层( 100 $\mu \mathrm{m})$ 会降 低阴极传质速率. 因此, 改善Fe/N/C阴极的传质是提高电池性能的重要途径.

本文选择高 $\mathrm{N}$ 含量的2-氨基苯并咪唑( $\mathrm{ABI}$ )为氮源, 通过水热聚合包覆在碳黑表面, 然后掺入 $\mathrm{FeCl}_{3}$, 经高温热解酸洗制 备了 $\mathrm{Fe} / \mathrm{N} / \mathrm{C}-\mathrm{ABI}$ 催化剂, 并与基于间苯二胺的微孔型 $\mathrm{Fe} / \mathrm{N} / \mathrm{C}$ 催化剂( $\mathrm{Fe} / \mathrm{N} / \mathrm{C}-\mathrm{PmPDA}$ )进行比较. Ar等温吸附-脱附结果表明, $\mathrm{Fe} / \mathrm{N} / \mathrm{C}-\mathrm{ABI}$ 催化剂具有较高的比表面积 $\left(662 \mathrm{~m}^{2} / \mathrm{g}\right.$ )和丰富的双级孔结构(微孔和介孔); 透射电镜表征显示 $\mathrm{Fe} / \mathrm{N} / \mathrm{C}-\mathrm{ABI}$ 催化 剂具有中空结构, 介孔孔径大约为 10-25 nm. 而Fe/N/C-PmPDA催化剂具有相当的比表面积 $\left(656 \mathrm{~m}^{2} / \mathrm{g}\right)$, 但以微孔为主, 基本 不含介孔. 旋转环圆盘电极 (RRDE) 测试表明, 在 $0.1 \mathrm{~mol} / \mathrm{L} \mathrm{H}_{2} \mathrm{SO}_{4}$ 溶液中, $\mathrm{Fe} / \mathrm{N} / \mathrm{C}-\mathrm{ABI}$ 催化剂的起始还原电位为 $0.92 \mathrm{~V}$, 在 $0.8 \mathrm{~V}$ 电位下质量电流密度可达 $9.21 \mathrm{~A} / \mathrm{g}$; 而 $\mathrm{Fe} / \mathrm{N} / \mathrm{C}-\mathrm{PmPDA}$ 催化剂具有相近的起始电位, 但具有更高的催化活性, 质量电流 密度为 $13.4 \mathrm{~A} / \mathrm{g}$. 氢氧燃料电池 $(\mathrm{PEMFC})$ 系统测试结果表明, $\mathrm{Fe} / \mathrm{N} / \mathrm{C}-\mathrm{ABI}$ 催化剂在 1 个背压和 $80^{\circ} \mathrm{C}$ 测试条件下的最大功率 密度达 $710 \mathrm{~mW} / \mathrm{cm}^{2}$, 高于 $\mathrm{Fe} / \mathrm{N} / \mathrm{C}-\mathrm{PmPDA}$ 催化剂 $\left(616 \mathrm{~mW} / \mathrm{cm}^{2}\right)$. 燃料电池与RRDE测试活性顺序的差异归结于Fe/N/C-ABI 的中空球状结构. PEMFC工作时阴极会产生大量的水, 很容易堵塞氧气传输通道. Fe/N/C-ABI的介孔结构可以作为水的 
产生和排除的缓存空间, 也有利于提高 $\mathrm{O}_{2}$ 传质, 从而提高燃料电池性能. 本文为具有高传质速率的 $\mathrm{Fe} / \mathrm{N} / \mathrm{C}$ 催化剂研制提供 了一种新思路.

关键词: 铁氮/碳催化剂; 非铂催化剂; 氧还原; 介孔; 空壳结构

收稿日期: 2016-04-17. 接受日期: 2016-05-11. 出版日期: 2016-07-05.

*通讯联系人. 电话: (0592)2180181; 电子信箱: zhouzy@xmu.edu.cn

\#通讯联系人. 电话: (0592)2180181; 电子信箱: xiaodong_yang@xmu.edu.cn

基金来源：国家重点基础研究发展计划(973计划, 2015CB932300); 国家自然科学基金(21373175, 21321062, 21361140374); 中央 高校基本科研业务费专项资金(20720150109).

本文的英文电子版由Elsevier出版社在ScienceDirect上出版(http://www.sciencedirect.com/science/journal/18722067). 